\title{
NOTES ON STRUMIGENYS FROM SOUTHERN OHIO, WITH DESCRIPTIONS OF SIX NEW SPECIES
}

\author{
By Laurence G. Wesson, JR., and ROBert G. Wesson \\ Baltimore, Md.
}

The following paper is a list, with biological notes, of 14 species of the peculiar and little known genus, Strumigenys, six of which are new and are here described. ${ }^{1}$ All the material was collected within 45 miles of Jackson, which is located centrally in southern Ohio.

\section{Strumigenys (Cephaloxys) pergandei Emery}

In a previous paper ${ }^{2}$ it was shown that $S$. pergandei lives, in southern Ohio at least, near the colonies of various other species of ants, hunting the Collembola which often abound in the nests of these other species. Since the publication of that paper, we have found $S$. pergandei on more than 30 occasions in this region, and only once was it not obviously associated with another ant. Stray workers have been found in nest galleries of Camponotus herculeanus subsp. pennsylvanicus (Degeer), Formica fusca (L.), and $F$. truncicola subsp. integra Nyl. Three workers were found in an outlying gallery of a $F$. fusca mound. The gallery led from the mound to a small kitchen midden to which the pergandei seemed to be going, not, as experiments have

1We wish to express our deep appreciation to Dr. M. R. Smith, U. S. National Museum, for his suggestions as to the relationship of several of the new forms, as well as for his loan of much cotype material for comparison.

The types of the new species are to be deposited in the collection of the Museum of Comparative Zoology, Cambridge, Mass. Paratypes, when present, will be deposited in the collections of Dr. C. H. Kennedy, Ohio State University, Columbus, Ohio, Dr. W. S. Creighton, College of the City of New York, the U. S. National Museum, Washington, D. C., the American Museum of Natural History, New York, and the authors.

2 Wesson, L. G., Jr., Contributions to the Biology of Strumigenys pergandei Em., Ent. News, vol. 47, pp. 171-174 (1936). 
indicated, for the debris there, but for the Collembola which lived about the refuse. Under a large, flat stone in maple woods was found a fine colony of $S$. pergandei in the center of a large $F$. fusca var. subserica Say colony the galleries of which surrounded the pergandei nest on all sides and below. Workers were observed in the galleries of about 28 additional nests of Aphænogaster fulva Roger under stones. Four or 5 pergandei workers could often be seen creeping away from the superficial galleries when a stone covering one of these nests was overturned. One such fulva-pergandei association was of special interest because of its similarity to the colony in the midst of the $F$. subserica nest described above. The pergandei were nesting in a shallow, nearly circular, earthen chamber about $3 \mathrm{~cm}$. in diameter, immediately under a large, flat stone covering a colony of $A$. fulva. Large, flattened chambers and galleries of the fulva surrounded the pergandei nest for at least $8 \mathrm{~cm}$. on all sides. The walls of the chamber separating the Strumigenys from the Aphænogaster were about $1 / 2 \mathrm{~cm}$. thick. With one exception we have always found $S$. pergandei in the soil, that one exception being in the log mentioned below under $S$. dietrichi M. R. Smith.

Some further notes from observations of this species are recorded here. The developmental periods are approximately: egg, 15 to 16 days; larval stage, about 42 days; pupal stage, about 18 days. On 3 occasions workers were seen to bring alternately left and right forelegs to the vertex of the head, rubbing the tarsi forward and placing them on the ground. Whether this was a cleaning operation or a means of transfering some substance to the substratum, or has some other significance is not known. The ant did not clean the tarsus after rubbing the head, nor did it rub any other part of its body. Workers of different colonies fight viciously when brought together. On the other hand, a colony will adopt the brood of another colony, even of a different species of the subgenus.

\section{Strumigenys (Cephaloxys) ornato Mayr}

Two workers were found near the kitchen midden of a colony of Aphænogaster fulva subsp. aquia (Buckley) which was nesting under a large stone in a rather moist 
hillside woods. Another colony was found in an almost identical situation in dense, oak woods. In the latter case a worker was first seen in a frequented gallery of $A$. fulva aquia under a large stone. The nest was located about $3 \mathrm{~cm}$. to one side of the stone, and consisted of an irregular cavity, perhaps just a crack in the soil, barely beneath the humus. It contained not more than 20 workers. Both localities were in Pike County.

\section{Strumigenys (Cephaloxys) deitrichi M. R. Smith}

We have taken this ant in Pike, Lawrence, and Adams Counties. On 4 occasions workers were found under the bark of somewhat decayed logs in open, dryish woods. In all of these logs have been colonies of other species of ants, such as Formica truncicola subsp. integra Nyl., Aphænogaster tennesseensis Mayr, A. lamellidens var. nigripes M. R. Smith, A. fulva Roger, Proceratium crassicorne var. vestita Emery, Ponera coarctata subsp. pennsylvanica Buckley. One long, decayed, hickory log, covered with a tough layer of bark, was remarkable in containing colonies of at least 11 species of ants, including 5 species of Strumigenys. The log, lying on the edge of some woods, extended from deep shade through a clump of bushes into broken sunlight. The ant species, in approximate order from shade to sun, were: Strumigenys deitrichi M. R. Smith, Ponera coarctata subsp. pennsylvanica Buckley, Aphænogaster fulva subsp. aquia, Buckley, Strumigenys pulchella Emery, Solenopsis molesta (Say), Strumigenys medialis new species, Strumigenys rostrata Emery, Proceratium crassicorne var. vestitum Emery, Lasius niger var. neoniger Emery, Strumigenys pergandei Emery, and Crematogaster lineolata (Say). Several workers of $S$. deitrich $i$ were found in the loose humus in the cedar grove described below under S. missouriensis M. R. Smith.

In none of these cases did we observe definite indications of an association between $S$. deitrichi and the other species of ants living near them, such as the presence of deitrichi workers in frequented galleries of the other.

\section{Strumigenys (Cephaloxys) clypeata Roger}

A nest of clypeata was found in the duff at the base of a small pine tree a few inches from a colony of Myrmica 
punctiventris Roger. The location was on a dry sandstone bluff in Jackson County on which many colonies of S. pergandei had been found. ${ }^{3}$

\section{Strumigenys (Cephaloxys) medialis, sp.n.}

Worker: (Pl. 3, fig. 1) : Length, $2.00 \mathrm{~mm}$.

Sides of head converging anteriorly, the occipital lobes posterior to the antennal insertions somewhat but not suddenly or strongly expanded; clypeus at greatest width $1 / 3$ the length of the head exclusive of the mandibles, evenly and broadly rounded, but narrower than in S. clypeata; mandibles when closed $1 / 4$, to $1 / 5$ the length of the remainder of the head, with the stout basal teeth hidden beneath the clypeus, the succeeding toothless space very short, the apical teeth comprising 5 pair of long, acute teeth decreasing somewhat in length anteriorly, and merging without a gap into the apical series of numerous smaller teeth; posterior border of head deeply excised; antennal scapes broadly curved on the basal third ; first joint of the funiculus distinctly shorter than the fourth, the terminal joint slightly longer than the remainder of the funiculus. Thorax as in $S$. clypeata; the dorsum of the mesonotum somewhat flattened, not marginate laterally; mesoepinotal suture distinct but not constricted; epinotal spines acute, slightly divergent, directed backwards ; infraspinal lamellæ narrow, uniform in width. Petiole, postpetiole and gaster as in $S$. clypeata and related species.

Head, thorax and petiole coarsely and densely reticulatepunctate, opaque; meso- and metapleura, dorsal surface of postpetiole and gaster smooth and shining; first gastric segment with numerous coarse longitudinal striae on the basal $1 / 3$; sculpture of the clypeus much finer than the rest of the head, densely and finely crenulate-punctate, subopaque. Hairs on the clypeus numerous, erect, anteriorly curved, narrowly squamose at their tips, those on the sides $1 / 5$ the width of the clypeus, those in the middle somewhat shorter; hairs on the rest of the head sparse, longer, thin, clavate, 1 or 2 on each side of the head very long and not clavate. Hairs on antennal scapes numerous, similar to those on the vertex of the head, curved toward the tip of the scapes;

\footnotetext{
${ }^{3}$ Wesson, L. G., Jr., Contributions to the Biology of Strumigenys pergandei Em., Ent. News, vol. 47, pp. 171-174 (1936).
} 
hairs on thorax irregular, long, thin, not clavate, the majority subappressed; gaster bearing 2 or 3 long hairs, usually near the base, a number of shorter hairs at the tip. Spongiform processes as in S. clypeata and related species.

Color dark ferruginous, the appendages slightly lighter, the gaster darker.

$S$. medialis possesses the general characteristics of $S$. clypeata and the species related to it. It may readily be separated from other forms, however, by (1) the longer mandibles, which are $1 / 4$, to $1 / 5$ the length of the head; (2) the more narrowly rounded clypeus, the surface of which is subopaque; (3) the pilosity of the clypeus, the hairs of which are longer, erect, feebly squamose and sharply curved apically, and (4) generally by the pilosity of the rest of the head and antennal scapes.

Type locality: Beaver, Pike County, Ohio.

Described from a colony of about 30 workers and several dealate females taken from the hickory log described above under S. deitrichi. The nest consisted of irregular cavities in the outer rotten portion of the log which appeared to be old galleries of beetle larvae. The colony was transferred to an artificial nest where, as did other species of Strumigenys we have had under observation, they fed on living springtails. In their hunting they were quite inactive, even more so than $S$. pulchella; the workers would remain in a crouching position, head close to the substratum, mandibles closed, antennae partially folded, for a great deal of the time. Occasionally some of the dealate females were observed hunting like the workers. Otherwise the hunting methods of this species resembled those of $S$. pergandei.

\section{Strumigenys (Cephaloxys) bimarginata, sp. n.}

Worker: (Pl. 3, fig. 2) : Length, $1.7 \mathrm{~mm}$.

Head, exclusive of mandibles, 3.3 times the greatest width of the clypeus, 5.7 times the length of the exposed portion of the closed mandibles. Viewed anteriorly, the sides of the head anterior to the antennal insertions are straight, converging, their projections lying along the exterior border of the closed mandibles; clypeus rather narrow but evenly rounded, not acute, flattened dorsally; clypeus viewed from 
the side with its edge broadly and deeply grooved along the entire lateral and anterior borders, thus giving the clypeus the appearance of having 2 margins, a thin but narrow upper margin and a thicker broader lower margin which projects beyond the upper margin and is visible when the clypeus is viewed anteriorly. Mandibles rather slender and elongate, the exterior border straight basally, feebly convex apically; basal tooth stout, partially concealed by the clypeus when the mandibles are closed; succeeding toothless space very short; apical teeth comprising 7 or 8 large irregular teeth which decrease in size anteriorly to merge into the apical series of numerous small teeth. Antennal scapes broadly curved basally, not angulate, fourth funicular joint slightly longer than the first; terminal joint slightly longer than the remainder of the funiculus. Sides of head posterior to the antennal insertions suddenly expanding to a broadly circular border so that that portion of the head appears subglobose when viewed anteriorly. Posterior border narrowly and rather deeply excised. Thorax essentially as in S. clypeata; mesoepinotal suture distinct but not constricted; median longitudinal carina prominent, especially on the basal surface of the epinotum. Petiole, postpetiole and gaster as in S. clypeata.

Head, thorax and petiole densely reticulate-punctate, subopaque; vertex of head with 8 or 10 broken irregular longitudinal rugae. Mandibles, clypeus, sides of mesonotum, meso- and metapleura, dorsum of the postpetiole and gaster smooth and shining; basal 1/4 of the first gastric segment with numerous coarse longitudinal striae.

Hairs on clypeus sparse, long, erect, more numerous on the edges, each hair being fairly straight at the base, curved and slightly enlarged on the apical $1 / 3,1 / 4$ to $1 / 2$ the width of the clypeus; hairs on vertex numerous, shorter, erect, clavate, curved anteriorly; antennal scapes with numerous hairs similar to those on the vertex but less clavate, curved toward the tips of the scapes; hairs on the thorax, petiole and postpetiole numerous, variable, those on the thoracic dorsum being rather long, slightly clavate, appressed, those on the petiole and postpetiole averaging longer, more erect and not clavate; gaster with sparse, long, slender, erect hairs. Spongiform processes as in S. clypeata and related species. 
Color ferruginous; mandibles, antennae and legs slightly lighter; gaster darker.

This very distinctive species is readily recognized by (1) the doubly margined character of the clypeal border; (2) the smooth and shining surface of the clypeus, and the more extensive shining areas on the thorax; (3) the shape of the head (4) the pilosity of the head.

Type locality: Cedar Mills, Adams County, Ohio.

Described from a single worker found under a piece of bark lying on the ground in a somewhat open, grassy spot in rather brushy cut-over woods. A deälated female belonging to this species was found about $15 \mathrm{~cm}$. distant in some thin, vegetable debris. Further search failed to reveal any more specimens.

\section{Strumigenys (Cephaloxys) manni, sp. $\mathrm{n} \mathbf{4}^{4}$}

Worker: (Pl. 3, fig. 3) : Length, 1.8-2.0 mm.

Head 2.5 times as long as the greatest width of the clypeus, 1.3 times the greatest width across the occipital lobes; viewed anteriorly, the sides of the head anterior to the antennal insertions are gently convergent, slightly convex, in outline merging without definite change of slope with the exterior borders of the mandibles; clypeus with lateral borders gently convergent, nearly straight, the anterior border truncate at, or a little anterior to, the point of intersection of the lateral and external mandibular borders; in some specimens, the anterior border is slightly emarginate, in others it is somewhat angularly convex in the middle, but the truncate appearance is not lost. Occipital lobes expanding suddenly but not strongly from the anterior portion of the head, at first broadly convex, then more strongly convex as the posterior border is approached; posterior border rather broadly and moderately excised. Mandibles 1/4, the length of the rest of the head, rather robust, the external border broadly and evenly convex; basal teeth very broad and short, partially concealed by the clypeus when the mandibles are closed, followed without an intervening toothless space by 5 pairs of moderately long acute teeth, the third

\footnotetext{
${ }^{4}$ It gives us pleasure to name this distinctive species after Dr. W. M. Mann, from whom we have received many kind favors.
} 
pair somewhat longer than the others, these acute teeth followed by the apical series of several much smaller teeth. Eyes small, comprising 10 or 12 facets. Antennal scapes $3 / 5$ the length of the funiculi, rounded but not angulate on the basal third; fourth joint of the funiculus very slightly shorter than the first, terminal joint as long as the remainder of the funiculus. Thorax as in S. clypeata, humeri and lateral margins smoothly rounded, somewhat flattened on the dorsum of the mesonotum, mesoepinotal suture distinct, slightly constricted; epinotal spines acute, thin; infraspinal lamellae narrow, not expanded ventrally. Node of petiole in profile rather prominent, broadly convex, the anterior slope rising suddenly but gently from the peduncle, the posterior slope declining very distinctly to the junction with the postpetiole.

Head, thorax and petiole reticulate-punctate, subopaque; mandibles, meso- and metapleura, dorsum of the postpetiole and gaster smooth and shining; first gastric segment with numerous, coarse, longitudinal striae on the basal $1 / 5$.

Hairs on head and thoracic dorsum numerous, moderately long, thin, curved and somewhat clavate at their tips; those on the clypeus shorter, curved laterally and anteriorly, a few on the borders of the clypeus slightly longer, curved posteriorly; hairs on antennal scapes erect, clavate on the anterior edge, more numerous and thinner dorsally, deflected toward the tips of the scapes; hairs on the thorax more irregular in length and distribution, and less clavate; hairs on the petiole, postpetiole and gaster very long, thin, very few on the gaster.

Color, light to dark ferruginous; tarsi and antennal funiculi slightly paler; gaster darker.

Type locality: Pike County, near Sinking Spring, Ohio.

Described from 32 workers obtained by sifting dirt and humus in the small cedar grove described below under $S$. missouriensis. The spot was situated at the base of a hill where the soil above the underlying limestone was only 5 to $8 \mathrm{~cm}$. deep. The ground was shaded by cedar and small oak trees and was covered with a rather thick, loose humus abounding with springtails.

In shape of the head, $S$. manni bears a superficial resemblance to $S$. margaritx Forel, but differs from that form in 
characters too numerous to mention. It is distinguished generally by (1) the decidedly truncate appearance of the clypeus; (2) the long and robust mandibles; (3) the mandibular dentition; (4) the relative prominence of the node of the petiole; (5) the character of the pilosity of the head and thorax; (6) the shorter terminal joints of the antennae.

\section{Strumigenys (Cephaloxys) rostrata Emery}

Jackson, Pike, Ross and Scioto counties.

We have taken this species in both soil and wood, sometimes in decidedly dry situations. Three colonies were found respectively in the hickory log mentioned under $S$. deitrichi, the decaying portion of a large elm tree in which also lived a colony of Aphaenogaster tennesseensis Mayr, and in a crevice in a stump in a wooded pasture, a few centimeters from another colony of $A$. tennesseensis. 3 colonies were taken on the edge of some dry oak woods, all in or on the humus just under the dry oak leaves, which, with some grass and herbs, covered the ground. The nesting site of one was a rotten hickory nut; the second was in some cavities in a small decayed stick; the third was living in a crevice of a partly buried board. Workers were found under the leaves in the vicinity of the nests, presumably foraging. They were not apparently associated with any other ants. A few dead springtails were found in one of the nests. On one occasion a colony of rostrata was found living in a chamber in dry soil under a stone. Under the stone there also ran a few galleries of Lasius umbratus mixtus var. aphidicola (Walsh).

A rostrata colony was transferred to an artificial nest for observation. While employing the same general methods of hunting springtails as the other species studied, the rostrata workers differ in being more active. Instead of crouching in one spot awaiting the advent of a springtail, they spend most of their foraging time moving over the debris in the nest. When a worker scents a springtail 2 or $3 \mathrm{~mm}$. away, she crouches, and, without touching it, tries various avenues of approach until she is so close that her mandibles almost touch the springtail. Then, head lowered, 
mandibles closed, antennae partially folded, she waits until the springtail, unaware of her presence, walks against her head. Then, seizing it with a quick snap of her mandibles, she quickly dispatches it with her sting. If, on the other hand, the springtail moves away from the ant, the latter repeats her approach. If the springtail shows no inclination to move within a few minutes, the ant often acts as though impatient, and tries to examine it with her antennae, or to take it in her mandibles.

\section{Strumigenys (Cephaloxys) pulchella Emery}

We have found this species on about 15 occasions, each time in dead wood. A typical habitat seems to be a log or stump or dead portion of a tree trunk, well-decayed for 3 or $4 \mathrm{~cm}$. beneath the bark, moist but not wet, warm but not in full sun. Such desirable situations are almost always inhabited by species of Aphrnogaster, Lasius niger var. americanus Emery, or Camponotus herculeanus pennsylvanicus var. ferrugineus (F.). Whether S. pulchella is definitely associated with the other species, as is $S$. pergandei, or whether it is simply a matter of such a situation being a very favorable one for other reasons, we have not determined. Although we have seldom taken pulchella workers in the frequented galleries of other ants, the colonies have seemed to be much more definitely associated with a larger species than chance alone would account for.

Several times when $\operatorname{logs}$ and stumps were broken open pulchella workers were seen carrying dead springtails in their mandibles, and when kept in an artificial nest they readily captured and killed these insects. They would, however, accept bits of dead flies after having been starved for a few days. Their hunting methods are similar to those of $S$. pergandei, but the workers are less active. They walk less around the galleries and amid the woody debris provided them and often crouch for hours at a cranny. When a springtail approaches, the worker merely lowers its head, turns in the direction of the quarry and waits. Only when the springtail touches the fore part of its head and mandibles does the pulchella snap and seize it. Once a dead springtail was gently pushed close to a waiting pulchella worker. The latter crept up to about the length of its head away, then crouched, holding its antennae partially folded. 
After waiting in this position for a considerable time, it rose, extended its antennae and vibrated them rapidly, then crouched again. This was repeated two more times before the ant, as if impatient after $3 / 4$ of an hour, walked up to the springtail and seized it.

Winged phases were taken from nests in mid August.

Strumigenys (Cephaloxys) missouriensis M. R. Smith

Four colonies and numerous stray workers were found in a cedar thicket in western Pike County. The first workers were seen in and around some little-used gallaries of Aphænogaster fulva aquia var. picea Emery under a small stone, and the colony was located about $30 \mathrm{~cm}$. away just beneath the humüs. Two other colonies were likewise in the soil, not more than $4 \mathrm{~cm}$. below the surface. The latter, however, were not visibly associated with any other ants. Scattered, stray workers were found just under the top layer of the humus. The cedar grove was located on the gently sloping base of a hill. Mingled with the cedars were a few small oaks and an occasional maple sapling. The soil was a black clay from 5 to $15 \mathrm{~cm}$. deep above the limestone bed rock. Above the clay was a thick, springy layer of loose decaying cedar needles, leaves and grass. Abounding in this debris were Ponera coarctata subsp. pennsylvanica Emery, Myrmecina graminicola (Latr.) subsp. and hordes of Collembola, as well as Strumigenys. Here, in an area of 3 by 9 meters, were found $S$. missouriensis M. R. Smith, $S$. manni new species, S. deitrichi M. R. Smith, and S. venatrix new species.

On careful comparison of our specimens with 2 worker cotypes loaned by Dr. M. R. Smith, we find that, although some of the workers agree closely with the cotypes, there is quite a perceptible amount of variation both among workers from the same colony and among the 4 colonies found. This variation lies almost entirely in the direction of forms which differ from the cotypes in the following details: (1) the head is slightly more robust; (2) the clypeus is slightly depressed in the middle; (3) the antennal scapes are somewhat more angulate; $(4)$ the sculpture is distinctly coarser; (5) the hairs on the head are larger, especially on the clypeus, and are fewer in number. 


\section{Strumigenys (Cephaloxys) reflexa, sp. n.}

Worker: (Pl. 3, fig. 4) : Length, 1.75-1.85 mm.

Head robust; exclusive of mandibles, 2 to 2.2 times as long as the greatest width of the clypeus, 1.3 times the greatest width across the occipital lobes; clypeus broadly rounded laterally, more narrowly rounded in the middle of the anterior border, the sides strongly scalloped; anterior portion of the head with a very broad distinct depression extending from the anterior portion of the clypeus to between the frontal carinae; occipital lobes broadly and rather evenly rounded; posterior border shallowly excised. Mandibles $1 / 6$ the length of the rest of the head, moderately robust, the external borders gently convex; the pair of basal teeth stout, just hidden when the mandibles are closed, succeeded by a toothless space which is equal to $1 / 3$ the length of the mandibles anterior to them, the toothless space followed by 4 or 5 pairs of rather short acute teeth which meet the apical series of numerous fine denticles. Antennal scapes rather sharply but not strongly angulate basally, $2 / 3$ as long as the funiculi; fourth funicular joint decidedly shorter than the first, the terminal joint almost half again as long as the remainder of the funiculus.

Thorax as in S. puchella; mesoepinotal suture distinct, slightly constricted. Epinotal spines broad and thin ; infraspinal lamellæ wide, broadly expanded ventrally.

Head, thorax and petiole reticulate-punctate, subopaque; head, especially on the dorsal posterior half coarsely tuberculate. Meso- and meta pleura, dorsum of the postpetiole and gaster, smooth and shining; first gastric segment with numerous coarse longitudinal striae on the basal $1 / 4$.

Clypeus with a few, short, irregular squamose hairs on the border; projecting from the edge of the clypeus on each side are 3 , occasionally 4 , long coarse squamose hairs which are strongly curved posteriorly; the rest of the dorsal surface of the head with more numerous erect, curved, narrow squamose hairs, curved predominately posteriorly; antennal scapes with 6 or 8 erect, clavate hairs on the outer border, most of which are slightly curved toward the bases of the scapes. Hairs on thorax sparse, irregular in length, erect, slightly enlarged apically. Petiole, postpetiole and gaster 
with long thin erect hairs, slightly enlarged apically. Legs and antennal funiculi with thin reclinate hairs. Spongiform processes as in S. pulchella.

Color ferrugineus; the gaster, darker.

Type locality: Jackson, Ohio.

We have compared S. reflexa with cotypes of S. missouriensis M. R. Smith and S. sculpturata M. R. Smith to both of which it is very similar. From $S$. missouriensis it may be distinguished by (1) the broad depression on the anterior portion of the head; (2) the much more strongly scalloped and sculptured head; (3) the less convex mandibles; (4) character of the pilosity. From S. sculpturata it differs in (1) the more robust head; (2) the rounded, non-truncate clypeus ; $(3)$ the slightly less abundant pilosity, particularly on the clypeus and gaster; (4) the appearance of the 6 large fringing clypeal hairs which are curved strongly backward -a feature by which this form may be easily recognized.

A colony of this species was found in a small, punky, partly-buried board in moderate shade in a backyard in Jackson. The colony was within a meter of a large log pile, and workers were found foraging among the woody debris at the base. Stray workers were discovered at 2 other places in the yard. An early attempt to find the above colony gives a check on the feeding habits of the species. A dead springtail was placed in front of a worker which had been discovered beneath a piece of bark. Apparently not greatly disturbed, the ant continued to stalk among the debris until she came within about $1 \mathrm{~mm}$. of the springtail. She then crouched and waited. After several minutes, the springtail was gently pushed toward the ant until it was partly on top of her head. The next instant the ant was to be seen holding the already dead springtail tightly in her mandibles and stinging it viciously. In a few seconds she started off at a rapid pace with the springtail. In the artificial nest the hunting methods of the workers were similar to those of $S$. pulchella, but even more sluggish.

Strumigenys (Cephaloxys) venatrix, sp. $n$.

Worker: (Pl. 3, fig. 5) : Length, 1.8-2.0 mm.

Head relatively slender, exclusive of the mandibles, 2.7 times the width of the clypeus, 1.4 times the greatest width 
across the occipital lobes; anterior portion of the head as viewed from the front slightly but perceptibly converging; clypeus with sides converging gently on the basal $2 / 3$, the anterior border very broadly rounded, somewhat flattened in appearance, but definitely not truncate; the dorsal surface evenly convex, the edges with very small, inconspicuous scalloping; the occipital lobes very broadly convex anteriorly, more strongly convex as the posterior border is approached; posterior border broadly and rather deeply excised. Mandibles somewhat less than $1 / 5$ the length of the head alone, rather slender, the external borders gently convex; basal teeth stout, partially concealed by the clypeus when the mandibles are closed, followed by a toothless space $1 / 3$ the length of the mandibles anterior to the basal teeth, the toothless space terminated by 4 or 5 pair of acute teeth somewhat irregular in length, but longer basally, which meet the apical series of smaller irregular denticles. Antennal scapes moderately curved, not angulate basally, about $3 / 5$ the length of the funiculi; fourth funicular joint slightly longer than the first, terminal joint slightly longer than the remainder of the funiculus. Thorax similar to that of $S$. pulchella; with a distinct and somewhat constricted mesoepinotal suture. Epinotal spines moderately broad and thin; infraspinal lamellae moderately broad, not or very slightly expanded ventrally. Petiole in lateral profile with node rather low but broad, the anterior slope rather short.

Head, thorax and petiole reticulate-punctate, subopaque, the reticulations, especially on the mesonotum, tending to form faint longitudinal rugae. Meso- and metapleura, dorsum of the postpetiole and gaster smooth and shining. First gastric segment with numerous coarse longitudinal striae on the basal $1 / 3$.

Hairs on the clypeus short, subappressed, moderately squamose; the sides of the clypeus bearing a fringe of 10 or 12 anteriorly curved hairs on each side, the hairs occurring as pairs, one hair in each pair long, very narrowly squamose, the others, arising medially to the first, shorter and more squamose; hairs on antennal scapes comprising 5 or 6 moderately long, narrowly squamose hairs on the external border curved toward the tips of the scapes, and in addition numerous thin, straighter, subappressed hairs. Thorax 
with sparse, moderately long, thin, reclinate hairs. Petiole, postpetiole and gaster with sparse, long, thin, curved, erect hairs. Legs with thin, moderately long, reclinate hairs. Spongiform processes approximately as in S. pulchella.

Color ferrugineus; gaster darker.

Type locality: Kitts Hill, southern Lawrence County, Ohio.

Similar to S. pulchella Emery and S. creightoni M. R. Smith. From S. pulchella, S. venatrix differs in (1) the narrower anterior portion of the head, and correspondingly a proportionately wider posterior portion; (2) the differently shaped clypeus; (3) the longer mandibles; (4) the different pilosity, particularly on the head. From S. creightoni, which it closely resembles in the shape of the head and mandibles, $S$. venatrix differs in (1) its entire and rounded clypeal borders; (2) the very different pilosity, especially on the vertex of the head and on the thorax.

Described from a colony containing about 60 workers.

Eight colonies and occasional scattered workers have been taken in Pike, Lawrence, Scioto and Adams Counties. The species is definitely a soil or humus dweller and forages for Collembola under the leaves and dead vegetable matter on the surface of the ground. So far as we can tell, it is not associated with other species for the purpose of obtaining the Collembola about their nest. Specific examples of the colonies may give a better idea of the habitus. A colony was found in a small opening near the edge of some young oak woods on a rather dry, gently-sloping hillside. The soil was a sandy clay. Several workers were first observed around a light cover of dead leaves. One of these, carrying a springtail in its mandibles, led to the nest, the entrance of which, was a tiny hole under a flake of stone in the middle of a small bare area $30 \mathrm{sq} . \mathrm{cm}$. in extent. Just below the surface, this hole widened out into a spacious, elongate chamber 5 to $10 \mathrm{~mm}$. in diameter and $10 \mathrm{~cm}$. in length, which appeared to be the hollow interior of a dead and decayed root. Another colony was found in the grassy humus on the edge of a bushy thicket in a field. A colony of Aphaenogaster fulva was under an adjacent stone. Four colonies, including the type, were found in a grassy clearing in some dry, open woods. Two of these colonies were on the surface in the 
tangled roots of the grass, while the other 2 were in the soil 2 to $8 \mathrm{~cm}$. below the surface. Galleries of Camponotus castaneus subsp. americanus Mayr ran close to one nest, but we were unable to find any connection between the two. Two colonies were found in the cedar thicket described above under $S$. missouriensis. One of these was nesting in an opening at the bottom of the humus, the other in a small cavity at the base of an old rotted cedar stump. Stray workers in these and other places were often found by pulling back the top cover of the humus in places where springtails were abundant.

\section{Strumigenys (Cephaloxys) abdita, sp. n,}

Worker: (Pl. 3, fig. 6) : Length, 2 mm.

Head, exclusive of mandibles, 1.3 times as long as the greatest width across the occipital lobes, 2.4 times as long as the greatest width of the clypeus; sides of anterior portion of head very slightly convergent; clypeus short and broad, the anterior border strongly flattened or truncate but not so as to make the head appear sharply rectangular ; mandibles rather long and slender, compressed dorso-ventrally, $1 / 4-1 / 5$ the length of the head alone, the internal border nearly straight, the external border straight on the basal half, gently convex on the apical half ; mandibles with a pair of large basal teeth partially concealed by the clyeus when the mandibles are closed; basal teeth followed by a toothless space $1 / 3$ the length of the portion of the mandibles anterior to them; terminal teeth comprising a compact row of 4 or 5 pair of large acute teeth, the second largest, the rest decreasing somewhat in length anteriorly, meeting and merging with little interruption into the apical series of a number of small teeth on the deflected tip of the mandibles; antennal scapes slightly angulate basally; first joint as long as the fourth; terminal joint 11/4 times as long as the rest of the funiculus. Humeri prominent, broadly angulate; median dorsal carina of thorax obsolescent; prominent lateral carinae present on base of epinotum terminating in the epinotal spines; epinotal spines somewhat longer than broad at the base, acute, flattened; infraspinal lamellae moderately wide dorsally, each suddenly expanding ventrally into a wide, 
rounded plate; mesoepinotal suture distinct, slightly constricted. Node of petiole in profile rather strongly convex above.

Head, thorax and petiole reticulate-punctate, subopaque, the sculpture on the clypeus decidedly finer than on the rest of the head; frontal area, sides of the mesonotum, mesoand metapleura, dorsum of the postpetiole and gaster smooth and shining, first gastric segment with numerous coarse longitudinal striae on the basal $1 / 3$.

Hairs on the clypeus numerous, moderately long, somewhat irregular, erect, the tips spatulate and curved horizontally, numbering about 30 on the dorsal surface, the border with 10 or 12 similar hairs curved anteriorly, the whole effect giving the clypeus a woolly appearance when viewed under low magnification. Pilosity of the rest of the head sparser, more curved and narrowly squamose; across the posterior border of the head is a transverse row of 4 evenly spaced, very long, thin, erect hairs; although 1 or 2 of these is sometimes missing, the position of the others is not altered. Antennal scapes with 5 or 6 irregular, moderately long, erect, narrow, squamose hairs on the external border, 4 or 5 similar but much shorter hairs on the dorsal surfaces. Thorax with sparse, moderately long, clavate, subappressed hairs and 1 or 2 much longer erect, thin hairs confined principally to the dorsum of the mesonotum. Node of petiole with numerous rather short, curved, blunt or clavate hairs. Postpetiole and gaster with very few long, slender, nearly straight hairs.

Color ferruginous; gaster darker.

Type locality: Jackson, Ohio.

Described from 3 workers found under a board and pieces of slate in a shaded spot in a backyard in Jackson. We did not succeed in locating the colony. It may be noted that of the 4 species of Strumigenys (pergandei, rostrata, reflexa, $a b d i t a)$ found in this yard, 2 were undescribed.

In order to facilitate the separation of the 6 new forms described above, we have modified Smith's key ${ }^{5}$ to include

${ }^{5}$ Smith, M. R., 1931, Revision of the Genus Strumigenys of America North of Mexico, Based on a Study of the Workers, Ann. Ent. Soc. Amer., 24, pp. 686-710. 
them, as well as several other species described ${ }^{6}$ since the publication of Smith's paper.

Key to Workers of Strumigenys, subgenus Cephaloxys of the United States.

1. Dorsal surface of first gastric segment clearly shagreened, subopaque; infraspinal lamella absent margaritæ Forel.

Dorsal surface of first gastric segment smooth and shining; infraspinal lamella present

2. Prothorax not only flattened, but also very strongly marginate laterally; head almost destitute of pilosity except for a pair of short, more or less erect, clublike hairs on the vertex.

membranifera simillima Emery

Prothorax not as above; head covered more or less abundantly with varied types of pilosity .............. 3

3. Sides of head as viewed from the front evenly and smoothly converging to the apices of the mandibles.

Sides of head subparallel or only slightly converging; external border of mandibles not lying on an anterior projection of the sides of the head

4. Clypeus very acute anteriorly; clypeal hairs few, long, erect, thickened, confined principally to the median anterior portion of the disk .... deitrichi M. R. Smith

Clypeus distinctly not as above .............................. 5

5. Clypeus smooth and shining …................................ 6

Clypeus opaque or subopaque …............................... 8

6. Clypeal hairs short, curved, apically enlarged

brevisetosa M. R. Smith

6Kennedy, C. H., and Schramm, M. M., 1933, A New Strumigenys with Notes on the Ohio Species, Ann. Ent. Soc. Amer., 25, pp. 95-104. (S. ohioensis)

Weber, N. A., 1934, A New Strumigenys from Illinois, Psyche, 41, pp. 63-65. (S. talpa)

Smith, M. R., 1935, Two New Species of North American Strumigenys, Ann. Ent. Soc. Amer. 28 pp. 214-216. (S. rohweri, S. brevisetosa) 
Clypeal hairs long, $1 / 2$ to $1 / 3$ times the width of the clypeus

7. Edge of clypeus in profile entire; clypeal hairs straight, thin, abundant; hairs on vertex sparse, hardly clavate clypeata var. laevinasis M. R. Smith

Edge of clypeus in profile deeply grooved; clypeal hairs sparse, curved, slightly enlarged apically; hairs on vertex numerous, shorter, clavate (Pl. 3, fig. 2)

bimarginata sp. $n$.

8. Clypeus with a few, long hairs, very much enlarged apically and principally on the anterior portion of the disk and also a pair of long, thick, recurved, but not suddenly enlarged hairs, posteriorly ornata Mayr

Clypeal pilosity distinctly not as above

9. Clypeal hairs straight, imperceptibly or not at all enlarged

Clypeal hairs curved, distinctly clavate or squamose 11

10. Clypeal hairs short, not over $1 / 8$ as long as the width of the clypeus ohioensis Kennedy and Schramm

Clypeal hairs long, $1 / 3$ to $1 / 2$ the width of the clypeus... pilinasis Forel

11. Clypeal hairs short, squamose, appressed 12

Clypeal hairs longer, more or less erect, clavate or narrowly squamose

12. Clypeus broadly and evenly rounded; the surface in large part concealed by the squamose hairs

clypeata Roger

Clypeus very broadly rounded, appearing somewhat truncate; clypeal surface almost entirely concealed by the spatulate hairs rohweri M. R. Smith

13. Clypeus rather sharply truncate in appearance; mandibles $1 / 4$, the length of the rest of head (Pl. 3, fig. 3) manni sp. n.

Clypeus broadly rounded, not truncate; mandibles shorter

14. Head broader; mandibles less than $1 / 5$ the length of the rest of the head; posterior border of head shallowly excised; toothless space of mandibles distinct talpa Weber 
Head narrower; mandibles slightly more than $1 / 5$ the length of the rest of the head; posterior border deeply excised; toothless space of mandibles small and indistinct. (Pl. 3, fig. 1.) medialis sp.n.

15. Mandibles longer, $1 / 3$ the length of the rest of head, clypeus truncate or emarginate or very broadly flattened anteriorly 16

Mandibles shorter; clypeus variable 17

16. Clypeus decidedly truncate anteriorly, thus giving the head a subrectangular appearance; antennal scapes not only short but very strongly angulate basally angulata M. R. Smith

Clypeus, although moderately truncate anteriorly, not enough to give a decidedly subrectangular appearance to the head; scapes longer and less angulate basally pergandei Emery

17. Clypeus truncate or subtruncate in front 18

Clypeus broadly rounded in front

18. Mandibles with large coarse teeth on their entire inner borders; clypeus broadly truncate or slightly emarginate rostrata Emery

Mandibles toothed on only a part of their inner border; clypeus truncate but never emarginate

19. Mandibles longer, $1 / 4$ to $1 / 5$ the length of the rest of head; clypeus very short and broad, the sides gently convergent (Pl. 3, fig. 6) abdita sp.n.

Mandibles shorter, $1 / 6$ the length of the rest of head; clypeus longer, the sides more strongly convergent

20. Hairs on head rather abundant, distinctly squamiform creightoni M. R. Smith Hairs on head less abundant, longer, and, although slightly enlarged apically, not squamiform sculpturata M. R. Smith

21. Sides of anterior portion of head gently and evenly convergent to the very broadly rounded clypeus; mandibles nearly $1 / 5$ the length of the rest of head Pl. 3, fig. 5) venatrix sp.n. 
Sides of anterior portion of head parallel, the clypeus evenly and broadly and broadly rounded on its entire border; mandibles shorter

22. Clypeus decidedly depressed in the middle, the sides strongly scalloped, each side with 3 large, erect, squamose hairs which are curved posteriorly; head robust; mandibles somewhat convex (Pl. 3, fig. 4) reflexa sp.n.

Clypeus not as above

23. Head relatively robust in proportion to its length; upper half rugulose or tuberculate; mandibles robust, convex missouriensis M. R. Smith

Head relatively slender in proportion to its length; surface, although reticulate-punctate, not tuberculate; mandibles slender and somewhat laterally compressed pulchella Emery

\section{LEGEND FOR PLATE III.}

Fig. 1. Strumigenys medialis sp. n., head of worker.

Fig. 2. Strumigenys bimarginata sp. n., head of worker.

Fig. 3. Strumigenys manni sp. n., head of worker.

Fig. 4. Strumigenys reflexa sp. n., head of worker.

Fig. 5. Strumigenys venatrix sp. n., head of worker.

Fig. 6. Strumigenys abdita sp. n., head of worker. 


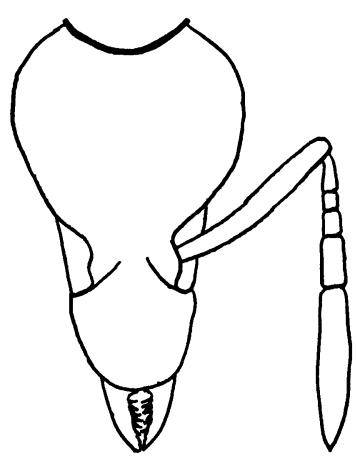

1

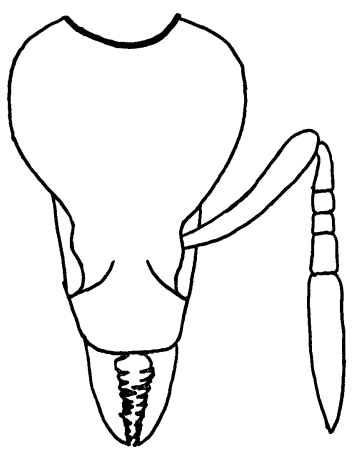

3

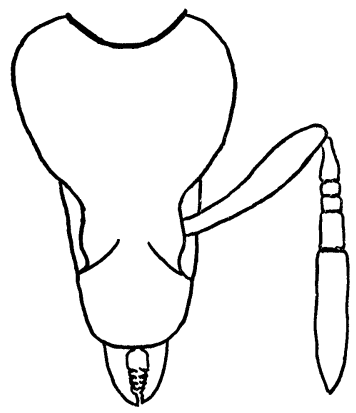

5

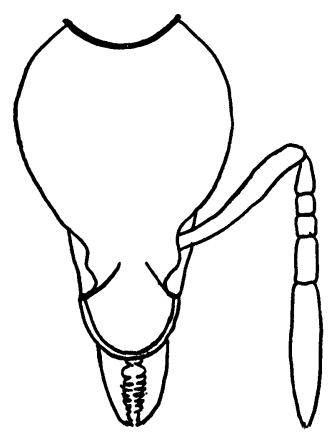

2

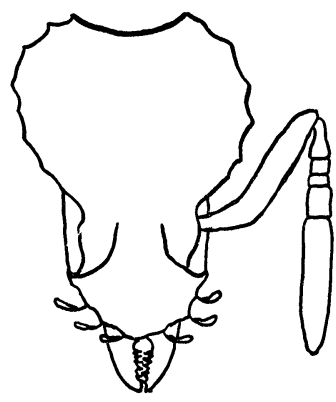

4

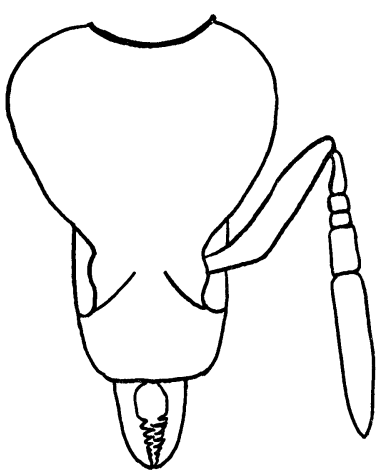

6

Wesson - Strumigenys 

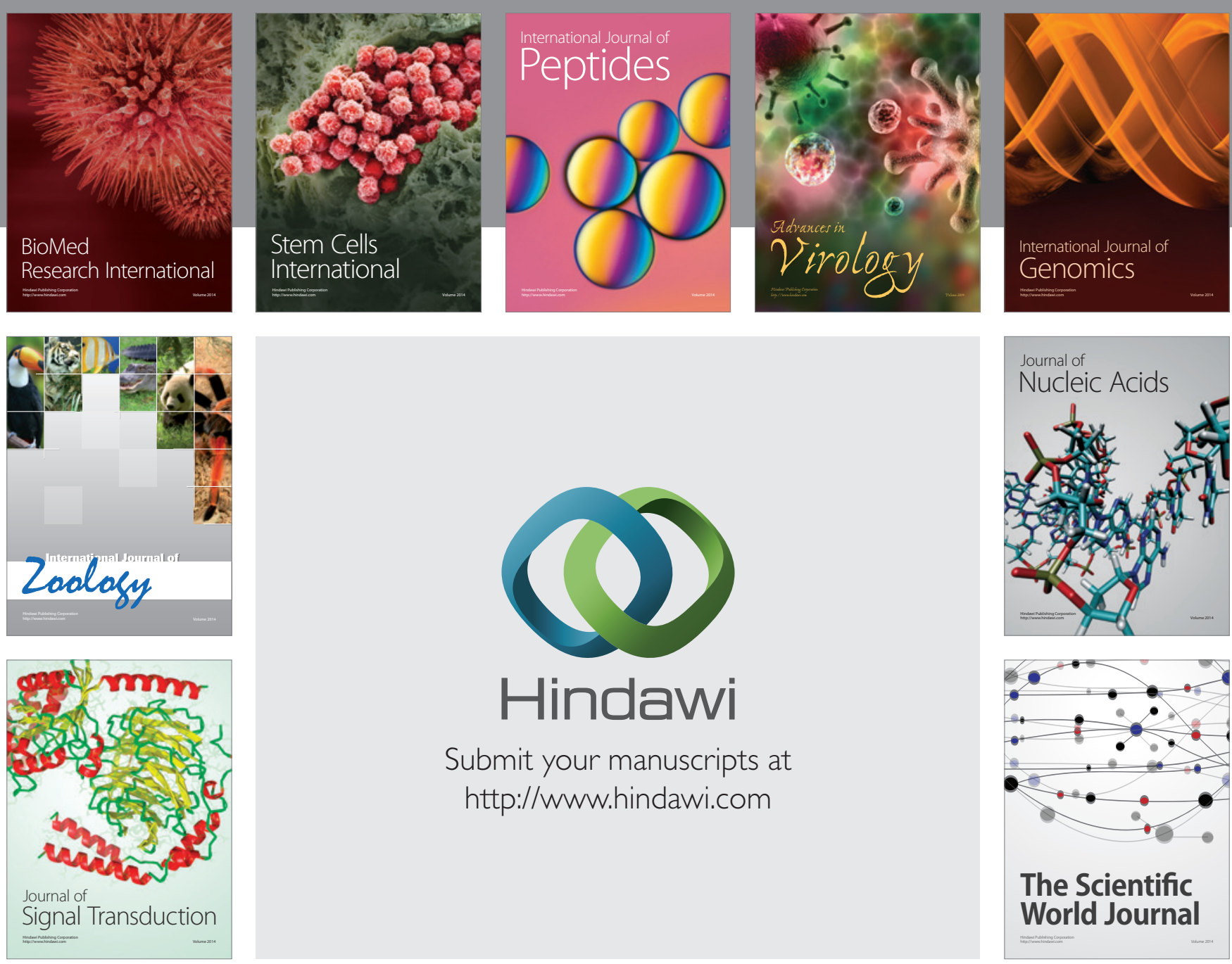

Submit your manuscripts at

http://www.hindawi.com
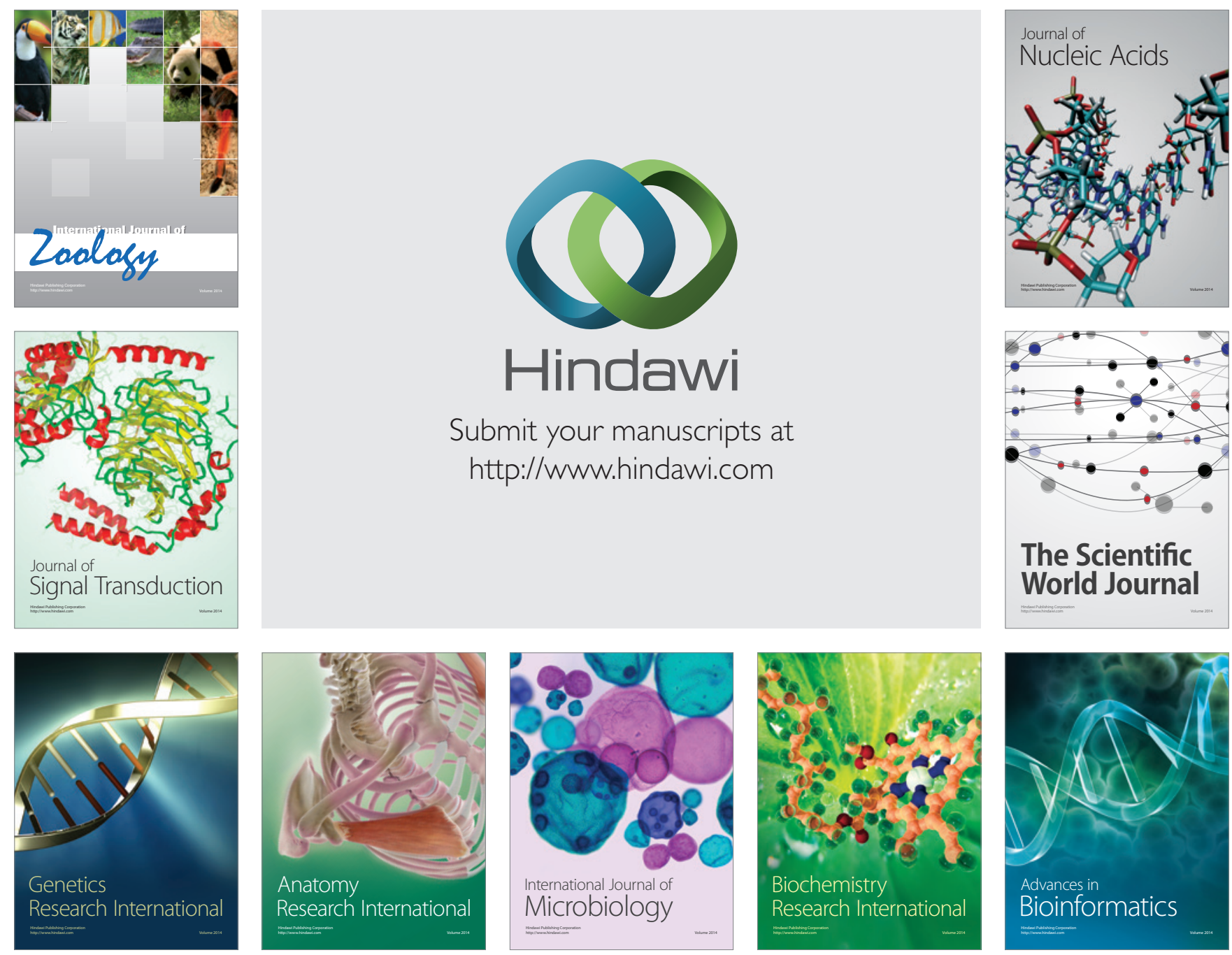

The Scientific World Journal
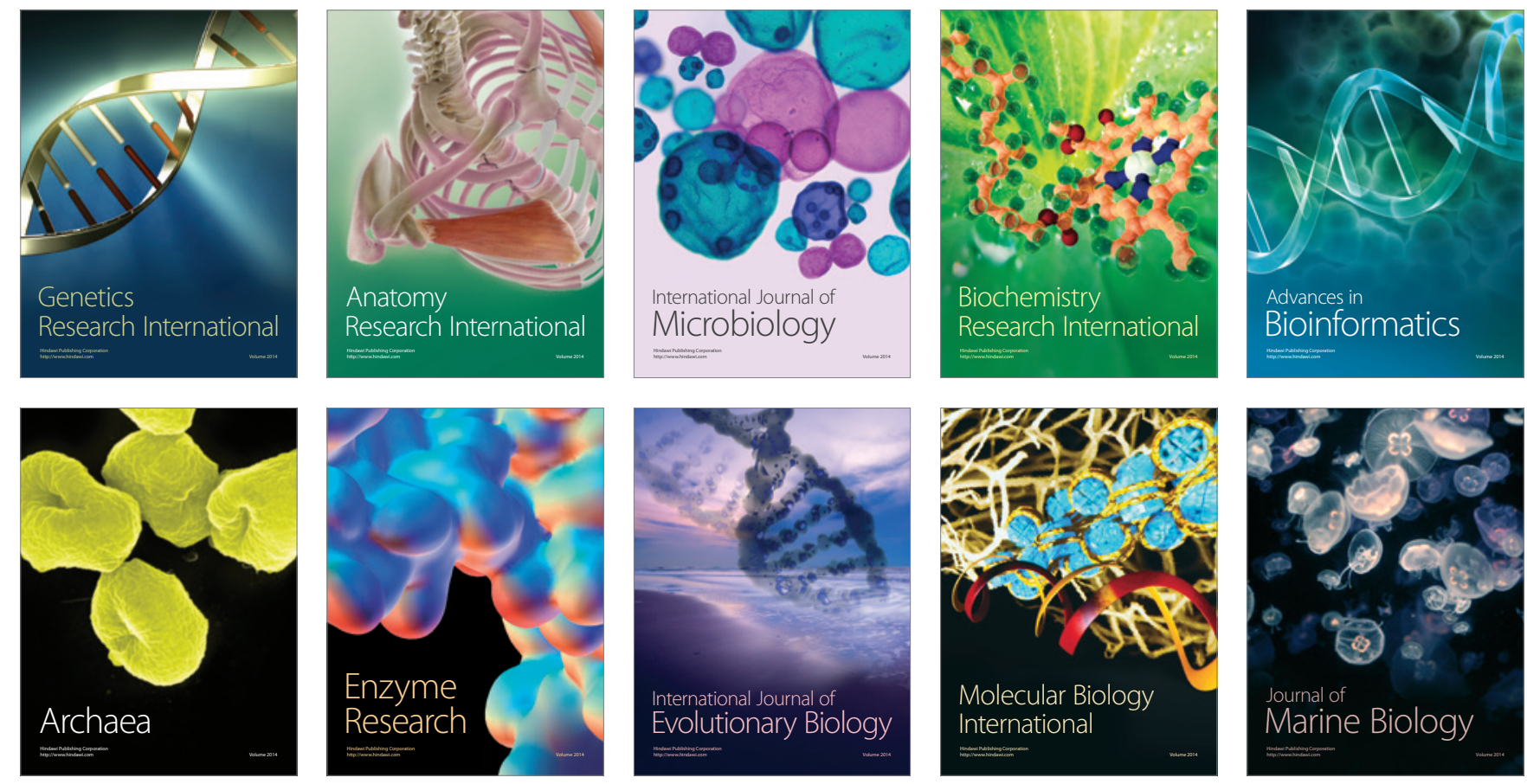